\title{
PENGARUH GAYA KEPEMIMPINAN KEPALA SEKOLAH TERHADAP KINERJA GURU SMA GLOBAL INDO-ASIA BATAM
}

\section{THE EFFECT OF SCHOOL OF LEADERSHIP LEADERSHIP ON INDO-ASIA BATAM GLOBAL TEACHER'S PERFORMANCE}

\author{
Gun Gun Gumilar ${ }^{1}$, T. Munzir ${ }^{2}$ \\ Program Studi Magister Manajemen Program Pascasarjana Universitas Riau Kepulauan \\ guns.ind@yahoo.com
}

\begin{abstract}
Abstrak
Gaya atau cara seorang kepala sekolah dalam kapasitasnya sebagai pemimpin sangat menentukan keberhasilan peningkatan kinerja guru di bawah pimpinannya. Tujuan penelitian ini adalah untuk mendapatkan data tentang (1) gaya kepemimpinan kepala sekolah dalam meningkatkan disiplin kerja, (2) gaya kepemimpinan kepala sekolah dalam meningkatkan motivasi kerja guru, (3) gaya kepemimpinan kepala sekolah dalam meningkatkan tanggung jawab dan (4) kendala-kendala yang dihadapi kepala sekolah dalam meningkatkan kinerja guru. Melalui pendekatan kualitatif dengan metode deskriptif, teknik pengumpulan data dilakukan melalui wawancara, observasi, dan studi dokumentasi. Penelitian ini menunjukkan bahwa (1) kepala sekolah menerapkan gaya kepemimpinan instruktif (telling) dalam meningkatkan kedisiplinan, (2) kepala sekolah menerapkan gaya kepemimpinan konsultatif (selling) dalam meningkatkan motivasi kerja guru, (3) kepala sekolah menerapkan gaya kepemimpinan delegatif(delegating) dalam meningkatkan tanggung jawab guru, dan (4) kendala-kendala yang dihadapi kepala sekolah yaitu menurunya kedisiplinan guru, kurangnya motivasi kinerja guru, dan rendah rasa tanggung jawab guru dalam pembelajaran. Disarankan agar kepada kepala sekolah dapat menerapkan gaya kepemimpinan yang lebih baik atau bervariasi agar tujuan yang diinginkan dapat tercapai dengan baik dan maksimal.
\end{abstract}

\section{Kata kunci: Gaya Kepemimpinan, Kepala Sekolah, Kinerja Guru}

\begin{abstract}
Style or manner of a school principal in his capacity as leader largely determine success in improving teacher performance under his leadership. The purpose of this study was to obtain data on (1) the principal's leadership style in improving labor discipline, (2) the principal's leadership style to motivate the work of teachers, (3) the principal's leadership style in increasing responsibilities and (4) constraints faced by principals in improving teacher performance. By using a qualitative approach, data collection techniques of observation, interviews and documentary studies, research subjects principals, and teachers, the data analysis techniques with qualitative analysis. This study shows that (1) the principal's leadership style instructive apply (telling) in improving discipline, (2) applying the principal consultative leadership style (selling) in improving work motivation of teachers, (3) the principal's leadership style apply discretionary (delegating) in improving the teacher's responsibility, and (4) the obstacles faced by the school principal that the decline in teacher discipline, teacher performance lack of motivation, and low sense of responsibility in the learning of teachers. It is recommended that the principals can implement a better leadership style or varied so that the desired goal can be achieved with good and maximum.
\end{abstract}

Keywords: Principal Leadership Styles, Head Master, Teacher Performance

\section{PENDAHULUAN}

Proses globalisasi yang mengubah wajah dunia, wajah masyarakat dengan dimensidimensi baru. Hal ini berarti manusia Indonesia haruslah dipersiapkan untuk menghadapi masyarakat global melalui tujuan pendidikan nasional memerlukan visi strategis yang 
dapat menjawab tantangan tersebut. Dalam Undang-Undang Nomor 20 Tahun 2003 tentang Sistem Pendidikan Nasional, Bab II Pasal 3 menetapkan: Pendidikan nasional berfungsi mengembang kemampuan dan membentuk watak serta peradaban bangsa yang bermartabat.

\section{Konsep Kepemimpinan Kepala Sekolah}

Kepemimpinan didefinisikan ke dalam ciri-ciri individual, kebiasan, cara mempengaruhi orang lain, interaksi, kedudukan dalam oragnisasi dan persepsi mengenai pengaruh yang sah dan menggerakan prilaku orang lain serta melakukan. Menurut Wahjosumidjo (2011:17) “Kepemimpinan diterjemahkan ke dalam istilah sifat-sifat, perilaku pribadi, pengaruh terhadap orang lain, pola-pola interaksi, hubungan kerja sama antarperan, kedudukan dari satu jabatan administrasi, dan persepsi dari lain-lain tentang legitimasi pengaruh".

Perlu dibedakan antara tipe dan gaya kepemimpinan. Kepemimpinan seseorang dapat digolongkan ke dalam salah satu tipe dan mungkin setiap tipe bisa memiliki berbagai macam gaya kepemimpinan. Salah seorang pemimpin yang memiliki salah satu tipe bisa menyesuaikan diri dengan situasi yang dihadapi dalam melaksanakan kepemimpinannya. Secara umum, Mukhtar dan Iskandar (2009:85) ada tiga tipe kepemimpinan dalam kehidupan suatu oragnisasi, termasuk organisasi sekolah, yaitu: (a) Tipe Otoriter, (b) Tipe Laissez-faire, dan (c) Tipe Demokratis. Perilaku kepemimpinan yang ditampilkan dalam proses manajerial secara konsisten disebut sebagai gaya (style) kepemimpinan. Gaya kepemimpinan lebih cenderung kepada situasi. Gaya kepemimpinan yang dimaksud sebagai cara berperilaku yang khas dari seorang pemimpin terhadap para anggota kelompoknya. Dengan demikian, gaya kepemimpinan adalah cara pemimpin berperilaku secara konsiten terhadap bawahan sebagai anggota kelompoknya. Gaya kepemimpinan pendidikan adalah cara seseorang pemimpin lembaga pendidikan dalam mengatur, mengarahkan, dan membimbing guruguru agar mereka bekerja sama untuk mencapai tujuan pendidikan. Kepemimpinan pendidikan merupakan posisi yang sangat menuntut kemampuan membaca dan memahami karakter, sifat dan kepribadian guru yang menjadi bawahannya.

Greenfield (Mulyasa 2013:19) mengemukakan bahwa "Indikator kepala sekolah efektif secara umum dapat diamati dari tiga hal pokok sebagai berikut: 1) komitmen terhadap visi sekolah dalam menjalankan tugas dan fungsinya, 2) menjadikan visi sekolah sebagai pedoman dalam mengelola dan memimpin sekolah, dan 3) senantiasa memfokuskan 
kegiatannya terhadap pembelajaran dan kinerja guru di kelas".

Kepala sekolah sebagai pemimpin yang baik adalah seorang kepala sekolah yang memiliki karakter atau ciri-ciri khusus yang mencakup kepribadian, keahlian dasar, pengalaman dan pengetahuan profesional, diklat dan ketrampilan profesional, pengetahuan administrasi dan pengawasan. Kemampuan yang harus diwujudkan kepala sekolah sebagai pemimpin dapat dianalisa dari kepribadian, pengetahuan terhadap tenaga kependidikan, visi dan misi sekolah, kemampuan mengambil keputusan dan kemampuan berkomunikasi. Gaya kepemimpinan kepala sekolah, paling tidak ada empat gaya kepemimpinan yang sering dilakukan kepala sekolah dan dipandang representative terhadap peningkatan kinerja guru, yakni gaya kepemimpinan transaksional, visioner, transformasional dan situasional.

\section{Peran dan Fungsi Kepala Sekolah}

Kepala sekolah merupakan jabatan karir yang diperoleh seseoarng setelah sekian lama menjabat sebagai guru. Seseorang diangkat dan dipercaya menduduki jabatan kepala sekolah harus memenuhi kriteria-kriteria yang disyaratkan untuk jabatan dimaksud. Wahjosumidjo (2011:83) menjelaskan "secara sederhana kepala sekolah dapat didefinisikan sebagai seorang tenaga fungsional guru yang diberi tugas tambahan untuk memimpin suatu lembaga atau sekolah dimana diselenggarakan proses belajar mengajar, atau tempat dimana terjadi interaksi antara guru yang memberi pelajaran dan murid yang menerima pelajaran”.

Kepala sekolah berfungsi sebagai pemimpin pendidikan berarti peningkatan mutu akan berjalan dengan baik apabila guru bersifat terbuka, kreatif dan memiliki semangat kerja yang tinggi. Dalam melaksanakan fungsinya, kinerja seorang kepala sekolah sering dirumuskan sebagai EMASLIM, singkatan dari Educator, Manager, Adminis-trator, Supervisor, Leader, Innovator, Motivator.

\section{Kompetensi Kepala Sekolah}

Kepala sekolah dalam mengelola satuan pendidikan disyaratkan menguasai keterampilan dan kompetensi tertentu yang dapat mendukung pelaksanaan tugasnya. Sahertian (Wahyudi 2012:28) mengartikan "kompetensi sebagai kemampuan melaksanakan sesuatu yang diperoleh melalui pendidikan dan latihan. Kompetensi diperoleh melalui pendidikan dan latihan dengan standari dan kualitas tertentu sesuai dengan tugas yang akan dilaksanakan". Secara umum tugas dan peran kepala sekolah memiliki lima dimensi komptensi sebagaimana termaktub pada Permendiknas Nomor 13 Tahun 2007, tentang 
"Standar Kepala Sekolah/ Madrasah, yaitu kompetensi kepribadian, manajerial, kewirausahaan, supervisi, dan kompetensi sosial".

\section{Konsep Kinerja Guru}

Kinerja adalah performance atau unjuk kerja. Kinerja merupakan terjemahan dari kata performance (job performance). Smith (Usman

2012:63) menyatakan bahwa "performan atau kinerja merupakan hasil kerja dari suatu proses. Artinya, hasil kerja yang dicapai oleh seseorang pegawai dalam melaksanakan tugas yang dibebankan kepadanya". Kinerja yang baik dapat dipengaruhi oleh kemampuan dan motivasi. Kemampuan merupakan hasil perpaduan antara pendidikan, pelatihan, dan pengalaman. Sedangkan motivasi adalah suatu daya pendorong (driveng force) yang menyebabkan seseorang berbuat atau melakukan sesuatu.

Standar kinerja perlu dirumuskan untuk dijadikan acuan dalam mengadakan perbanding- an terhadap apa yang dicapai dengan apa yang diharapkan, atau kualitas kerja adalah wujud perilaku atau kegiatan yang dilaksanakan dan sesuai dengan harapan dan kebutuhan atau tujuan yang hendak dicapai secara efektif dan efesien. IndikatorIndikator kinerja guru menurut Rebore (Usman 2012:94) "menyangkut dengan (1) kinerja pembelajaran, (2) kinerja profesional, dan (3) kinerja personal”. Berkenaan dengan kepentingan penilaian terhadap kinerja guru, Georgia Departemen of Education telah mengembangkan teacher performance asses- sment instrument yang kemudian dimodifikasi oleh Depdiknas menjadi Alat Penilaian Kinerja Guru (APKG). APKG merupakan alat pengukur kemampuan guru dalam bentuk kompetensi yang bersifat generic essentials, maka dalam hal ini APKG hanya mengukur kompetensi yang dimiliki atau dapat diasumsikan oleh guru.

Salah satu faktor utama yang menentukan mutu pendidikan adalah guru. Gurulah yang berada di garda terdepan dalam menciptakan kualitas sumber daya manusia. Guru berhadapan langsung dengan para peserta didik di kelas melalui proses belajar mengajar. Di tangan gurulah dihasilkan peserta didik yang berkualitas, baik secara akademis, skill (keahlian), kematangan emosional, dan moral serta spiritual. Sementara itu, menurut Mulyasa (Kunandar 2009:42) sedikitnya ada tujuh kesalahan yang sering dilakukan guru dalam pembelajaran, yaitu: “(1) mengambil jalan pintas dalam pembelajaran, (2) menunggu peserta didik berperilaku negatif, (3) menggunakan destructive disipline, (4) mengabai-kan perbedaan peserta didik, (5) merasa paling pandai dan tahu, (6) tidak adil (diskriminatif), dan (7) 
memaksa hak peserta didik".

Guru merupakan ujung tombak keberhasilan pendidikan dan dianggap sebagai orang yang berperan penting dalam pencapaian tujuan pendidikan yang merupakan percerminan mutu pendidikan. Beberapa faktor yang mempengaruhi kinerja guru yang dapat diungkap, antara lain: (1) Kepribadian; (2) Pengembangan profesi guru; (3) Pembelajaran yang diidentikkan dengan kata "mengajar": (4) Terbinanya hubungan dan komunikasi di dalam lingkungan sekolah; (5) Hubungan mutualisme sekolah dengan masyarakat; (6) kesejahteraan; dan (7) Iklim sekolah.

\section{METODOLOGI}

Metode penelitian yang digunakan adalah metode deskriptif dengan menggunakan pendekatan kualitatif untuk mengkaji permasalahan dan memperoleh makna yang lebih mendalam tentang Gaya Kepemimpinan Kepala Sekolah dalam Meningkatkan Kinerja Guru pada pada SMA Global Indo-Asia Batam.

Lokasi dalam penelitian ini peneliti laksanakan pada SMA Global Indo-Asia Batam., dengan diobservasikan oleh kepala sekolah, wakil kepala sekolah serta teman-teman sejawat. Penelitian ini berlangsung selama 3 (tiga) bulan, yaitu pada bulan September dan November 2013. Sedangkan subjek penelitian ini adalah kepala sekolah dan guru-guru pada SMA Global Indo-Asia Batam. yang yang ditentukan secara acak. Salah satu teknik yang digunakan adalah memeriksa derajat kepercayaan atau kredibilitasnya.

Uji Kredibilitas data dapat dipercaya melalui kriteria kredibilitas, reliabilitas dan objektifitas. Teknik pengumpulan data merupakan langkah yang paling strategis dalam penelitian, karena tujuan utama dari penelitian adalah mendapatkan data. Jadi, dalam penelitian ini teknik pengumpulan data ialah melalui wawancara, observasi dan dokumentasi. Selanjutnya, teknik Analisis data terdiri tiga alur kegiatan, yaitu: Reduksi data, Penyajian data dan Penarikan kesimpulan atau verifikasi.

\section{PEMBAHASAN}

Gaya kepemimpinan kepala sekolah dalam meningkatkan disiplin guru; yaitu kepala sekolah berusahan menjadi teladan di lingkungan sekolah dengan cara datang lebih awal dan pulang paling akhir. Gaya kepemimpinan yang diterapkan kepala sekolah dalam meningkatkan disiplin guru, dari hasil wawancara terungkap bahwa digunakan gaya kepemimpinan membertitahukan (telling), gaya ini dilakukan dengan menemui guru-guru secara personal. Gaya kepemimpinan telling ini dilakukan oleh kepala sekolah pada saat rapat 
dewan guru, sehubungan dengan gaya telling kepala sekolah setiap pagi, cara yang dilakukan dengan duduk dikantor dewan guru, ia memantau setiap guru yang datang dan lansung mengingatkannya bila saat jam mengajar tiba.

Gaya kepemimpinan kepala sekolah dalam meningkatkan motivasi kerja guru, yaitu kepala sekolah berusaha untuk memotivasi guru dengan menetapkan standar kerja yang tinggi yang berbasis pada peningkatan mutu. Kepala sekolah sangat menyadari dan mengerti bahwa pada hakikatnya guru-guru adalah manusia biasa dan tidak pernah luput dari kesalahan dan juga memberikan perhatian penuh dalam menindaklanjuti keluhan serta harapan yang diharapkan oleh guru untuk menciptakan lembaga sekolah yang berkualitas.

Gaya kepemimpinan kepala sekolah dalam meningkatkan tanggung jawab guru, yaitu Kepala sekolah juga memberikan penghargaan, insentif, dan kesejahteraan lain yang luar dari kesejahteraan sertifikasi yang telah ditetapkan dalam skala nasional. Dengan adanya penghargaan, insentif, dan kesejahteraan tersebut diharapkan dapat menambah kebutuhan-kebutahan lain yang kian meningkat. kepala sekolah menganut gaya kepemimpinan demokratis dalam meningkatkan tanggung jawab guru-guru. Dalam peningkatan tanggung jawab guru, kepala sekolah berusaha mendorong dan meningkatkan mengairahkan guru-guru untuk bekerja baik dalam kegiatan ekstrakurikuler maupun nonekstra-kurikuler.

Kendala-kendala yang dihadapi oleh kepala sekolah dalam meningkatkan kinerja guru, dengan cara mengatur administrasi kelas dan memberlakukan peraturan-peraturan tepat waktu baik dari segi kehadiran maupun ketepatan jadwal mengajar. Selanjutnya kendalakendala kepala sekolah yang dihadapi kepala sekolah dalam motivasi kerja guru, yaitu melalui kesiapan mental dan fisiknya dalam mengajar. Kepala sekolah selalu mengingat guru-guru agar selalu menjaga kesehatan, baik dirinya sendiri maupun keluarga. Upaya yang dilakukan kepala sekolah dalam meningkatkan motivasi guru-guru dengan cara memberi wejengan, semangat, dan teratur menjaga kesahatan, terutama semangat dalam mengajar di kelas.

Kendala yang dihadapi kepala sekolah dalam meningkatkan tanggung jawab guru adalah masih ditemukan guru-guru yang kurang mampu menjabarkan RPP dan silabus dengan benar, sehingga guru-guru tersebut hanya menjalankan tugas mengajar saja tanpa diserta dengan perencanaan yang matang. Upaya yang dilakukan kepala sekolah dalam menyikapi masalah tanggung jawab guru yaitu dengan cara mengadakan pelatihan bagi guru- 
guru yang belum teratur dalam menjabar RPP dan silabus, bahkan kepala sekolah sering meminta bantuan kepada pengawas atau dinas terkait untuk mensosialisasikan guru-guru dalam peningkatan administrasi guru.

Disiplin sekolah merupakan sesuatu hal yang mudah diucapkan, tetapi sukar dilaksanakan; bukan hanya oleh peserta didik, tetapi oleh guru bahkan oleh kepala sekolah. Disiplin adalah suatu keadaan tertib, ketika orang-orang yang tergabung dalam suatu sistem tunduk pada peraturan-peraturan yang ada dengan senang hati. (Mulyasa 2013:191) mengemukakan "disiplin sekolah dapat diartikan sebagai keadaan tertib, ketika guru, kepala sekolah dan staf, peserta didik yang tergabung dalam sekolah tunduk kepada peraturan yang telah ditetapkan dengan senang hati”. Membina disiplin di sekolah perlu dimulai dengan prinsip yang sesuai dengan tujuan pendidikan nasional, yakni sikap demokratis. Sehubungan dengan itu, dalam menentukan peraturan disiplin perlu berpedoman pada hal berikut, yakni dari, oleh dan untuk peserta didik, sedangkan guru tut wuri handayani.

Dalam menegakkan disiplin sekolah, gaya kepemimpinan kepala sekolah adalah sangat menentukan jalannya roda kepemimpinan sekolah. Ada bermacam-macam gaya yang dapat diterapkan kepala sekolah, tetapi untuk mendisiplinkan guru, staf dan siswa, maka kepala sekolah cocok menerapkan gaya instruktif (telling). Wahyudi (2012:140) menyebutkan: Gaya instruktif diterapkan pada guru yang tidak mampu dan tidak berani memikul tanggung jawab, bila menjalankan tugas membutuhkan penjelasan, pengaturan/ pengarahan dan supervisi secara khusus. Gaya kepemimpinan yang bersifat instruktif (G1) tepat untuk diterapkan pada guru yang tidak mampu dan tidak mau menerima tanggung jawab. Kepala sekolah melaksanakan pengawasan secara ketat, dengan demikian derajat hubungan manusia pada kategori rendah akan tetapi perhatian terhadap organisasi tinggi.

Kepala sekolah banyak memberikan instruksi kepada guru dan melaksanakan pengawasan ketat. Pada gaya instruktif, kepala sekolah lebih dominan dalam memberikan pengarahan tentang tugas terhadap guru dan sedikit dalam perilaku hubungan (tugas tinggi dan hubungan rendah). Selain gaya instruktif, kepala sekolah juga menerapkan gaya otoriter guna untuk meningkatkan kedisiplinan guru. Apabila guru-guru tidak mengindahkan arahan dari kepala sekolah, maka baru menerapkan gaya otoriter. Engkoswara dan Kamariah (2011:181) menyatakan "ototiter adalah gaya kepemimpinan yang menekan pada kekuasaan dan kepatuhan anggota secara mutlak".

Motivasi adalah tenaga pendorong atau penarik yang menyebabkan adanya perilaku 
seseorang ke arah suatu tujuan tertentu. Motivasi kerja berkaitan dengan apa yang diinginkan manusia (tujuan), mengapa ia menginginkan hal tersebut (motif), dan bagaimana ia mencapai tujuan tersebut (proses). Mulyasa (2013:196) menyatakan: Motivasi merupakan salah satu faktor yang turut menentukan kefektifan dan keberhasilan pembelajaran, karena peserta didik akan belajar dengan sungguh-sungguh apabila memiliki motivasi yang tinggi.

Banyak cara yang dapat dilakukan guru untuk membangkitkan motivasi belajar peserta didik, antara lain melalui kehangatan dan keantusiasan, menimbulkan rasa ingin tahu, mengemukakan ide yang bertentangan, dan memerhatikan minat belajar peserta didik. Sehubungan dengan itu, Howard (Mulyasa 2013:200) "seorang guru sebaiknya memiliki rasa ingin tahu, mengapa dan bagaimana anak belajar dan menyesuaikan dirinya dengan kondisi-kondisi belajar dalam lingkungan”. Dalam meningkat motivasi guru, kepala sekolah menerapkan gaya kepemimpinan konsultatif (selling). Di dalam penerapan gaya ini, guru tidak mampu melaksanakan tugas secara mandiri tetapi mau mengambil tanggung jawab.

Penerapan gaya konsultatif ini, kepala sekolah masih menunjukkan perilaku mengarahkan tugas-tugas guru dan sering memberikan dorongan dan motivasi terhadap penyelesaian tugas (tugas tinggi dan hubungan tinggi). Selain gaya konsultatif di atas, kepala sekolah juga menerapkan gaya otoriter guna untuk meningkatkan motivasi kerja guru. Guru- guru yang tidak mengerjakan tugas dengan benar maka kepala sekolah akan menerapkan gaya otoriter tersebut. Engkoswara dan Kamariah (2011:181) menyatakan "ototiter adalah gaya kepemimpinan yang menekan pada kekuasaan dan kepatuhan anggota secara mutlak".

Guru merupakan faktor yang sangat dominan dalam pendidikan pada umumnya, karena guru memegang tanggung jawab dalam proses pembelajaran, di mana proses pembelajaran merupakan inti dari proses pendidikan secara keseluruhan. Rusman (2009:325) menjelaskan "proses pembelajaran merupakan suatu proses yang mengandung serangkaian perbuatan guru dan siswa atas hubungan timbal balik yang berlangsung dalam situasi edukatif untuk mencapai tujuan tertentu, di mana dalam proses tersebut terkandung multiperan dari guru". Jadi tanggung jawab guru bukan sekedar menstransfer ilmu pengetahuan kepada anak didik. Melainkan, guru juga berkewajiban membentuk watak dan jiwa anak didik yang sebenarnya sangat memerlukan masukan positif dalam bentuk ajaran agama, ideologi, dan lain-lain. Memberikan bimbingan sehingga anak didik memiliki 
jiwa dan watak yang baik, mampu membedakan mana yang baik dan buruk, mana yang halal dan haram, adalah termasuk tugas guru.

Gaya kepemimpinan kepala sekolah yang cocok diterapkan dalam meningkat- kan tanggung jawab guru ini adalah gaya instruktif dan gaya delegatif. Wahyudi (2012:140-141) menyebutkan: Gaya instruktif diterapkan pada guru yang tidak mampu dan tidak berani memikul tanggung jawab, bila menjalankan tugas membutuhkan penjelasan, pengaturan/ pengarahan dan supervisi secara khusus. Kepala sekolah melaksanakan pengawasan secara ketat, dengan demikian derajat hubungan manusia pada kategori rendah akan tetapi perhatian terhadap organisasi tinggi. Dalam gaya delegatif "kepala sekolah sedikit sekali memberikan pengarahan, karena para guru dapat menjabarkan program-program innstitusi dan melaksanakan dengan, para guru dapat mengatasi persoalan secara mandiri dan memutuskan solusi yang terbaik untuk kepentingan keberhasilan pencapaian tujuan pendidikan".

Kendala suatu masalah dalam pembelajaran, terutama yang dialami oleh guru- guru bidang studi. Kendala tersebut bisa datang dari guru itu sendiri, dari peserta didik, lingkungan keluarga, atau karena faktor fasilitas, dan termasuk internal sekolah. Kepala sekolah dalam menerapkan kedisiplinan kepada guru yang kurang disiplin yaitu dengan cara mengatur administrasi kelas dan memberlakukan peraturan-peraturan tepat waktu baik dari segi kehadiran maupun ketepatan jadwal mengajar. Menurut Wikipedia (Yamin dan Maisah 2009:48) "disiplin merupakan bentuk pelatihan yang menghasilkan suatu karakter atau perilaku khusus yang menghasilkan perkembangan moral, fisik, dan mental untuk tujuan tertentu". Dalam meningkatkan kedisiplinan guru, kepala sekolah menerapkan gaya intruktif.

Kendala lain yang dihadapi kepala sekolah dalam meningkat kinerja guru adalah motivasi. Menurut Mulyasa (2013:195) “Motivasi adalah tenaga pendorong atau penarik yang menyebabkan adanya perilaku seseorang ke arah suatu tujuan tertentu. Motivasi berkaitan dengan apa yang diinginkan manusia (tujuan), mengapa ia mengingin-kan hal tersebut (motif), dan bagaimana ia mencapai tujuan tersebut (proses)". Selanjutnya, kendala dalam meningkatkan tanggung jawab guru dengan mengatur pembagian tugas mengajar. Pembagian tugas tersebut harus adil dan merata sesuai dengan bidang keahliannya masingmasing. Guru adalah orang yang harus bertanggung jawab terhadap pendidikan muridmurid, baik secara individual ataupun secara klasikal, baik di sekolah maupun di luar 
sekolah, Supardi (2013:92) yaitu: Guru yang bertanggung jawab adalah guru yang mengetahui, memahami nilai-nilai, norma-norma (kesusilaan, kesopanan, moral, sosial, maupun keagamaan) dan selalu berusaha untuk menyesuaikan segala tindak-tanduk dan perilakunya sesuai dengan nilai dan norma-norma tersebut. Guru bertanggung jawab atas segala tindakannya kepada sstakesholder pendidikan maupun kepada Tuhan Yang Maha Esa dalam kegiatan pembelajaran yang dilakukan di sekolah (di kelas atau di luar kelas).

\section{KESIMPULAN DAN SARAN}

\section{Kesimpulan}

Berdasarkan hasil penelitian, maka dapat diberi beberapa kesimpulan, yaitu: Gaya kepemimpinan kepala sekolah dalam meningkatkan disiplin guru adalah dengan menggunakan gaya kepemimpinan otoriter dan demokratis yang melihat ketepatan waktu untuk memasuki kelas sesuai dengan jadwal yang telah ditetapkan sekolah.

Gaya kepemimpinan kepala sekolah dalam meningkatkan motivasi kerja guru pada SMA Global Indo-Asia Batam lebih cenderung menggunakan gaya kepemimpinan demokratis yaitu dengan memberikan kesempatan kepada guru-guru untuk melanjutkan studi banding ke sekolah dan memberikan kesempatan dalam menindak lanjuti keluhan dan harapan guru. Gaya kepemimpinan kepala sekolah untuk meningkatkan tanggungjawab guru dalam melaksanakan proses pembelajaran adalah dengan menerapkan gaya kepemimpinan demokratis. Kendala-kendala yang dihadapi kepala sekolah dalam meningkatkan kinerja guru yaitu masih ada guru yang kurang siap dalam mengajar. Masih banyak guru-guru yang belum mengikuti pelatihan-pelatihan. Di samping itu, terdapat kurangnya disiplin guru, motivasi kerja dan tanggung jawab guru dalam pembelajaran, sehingga kepala sekolah akan menerapkan bermacam-macam jenis gaya kepemimpinan.

Gaya kepemimpinan berpengaruh terhadap kinerja Guru SMA Global Indo-Asia Batam. Hasil penelitian ini mendukung hasil penelitian Zainudin dan Ratnasari (2015) yang menyatakan bahwa Gaya Kepemimpinan Berpengaruh Terhadap Kinerja Guru Sekolah Dasar Kecamatan Batu Ampar Kota Batam.

\section{Saran}

Dari uraian kesimpulan di atas, maka saran kepada kepala sekolah agar sesering mungkin menggunakan gaya kepemimpinan demokratis, terutama dalam pembagian tugas mengajar guru secara adil dan mengikutsertakan guru-guru dalam berbagai kegiatan seperti: training, seminar, MGMP. Kepala sekolah, sebaiknya jangan terlalu sering menggunakan 
gaya kepemimpinan otoriter, karena dikhawatir akan berdampak pada: (1) guru semakin malas dan bosan dalam melaksanakan tugas mengajar, (2) tanggung jawab guru dapat terabaikan, dan (3) wibawa kepala sekolah sebagai pimpinan menurun atau hilang.

Kepada kepala sekolah untuk terus berupaya meningkatkan kinerja guru dengan memberikan penghargaan kepada guru yang berprestasi, memberikan perhatian baik dari segi materi maupun non materi, melibatkan guru- guru dalan menyusun program sekolah, mendengar-kan ide-ide guru serta memberi rasa aman untuk guru-guru sehingga guru-guru merasa nyaman dan memiliki terhadap peningkatan sekolah. kepala sekolah bersama- sama dengan Dinas Pendidikan terkait, pengawas dan stakesholders lainnya, diharapkan dapat menyediakan sarana dan prasarana yang memadai dan dibutuhkan oleh guru dalam menunjang pembelajaran pada SMA Global Indo-Asia Batam.

Kepala sekolah dalam meningkatkan kinerja guru, hendaknya menjadi kepala sekolah yang profesional, karena dengan bermacam-macam gaya kepemimpinan kepala sekolah yang diterapkannya.

\section{REFERENSI}

Danim, Sudarwan. (2012). Visi Baru Manajemen Sekolah. Jakarta: PT. Bumi Aksara.

Engkoswara dan Komariah, Aan. (2011). Administrasi Pendidikan. Bandung: Alfabeta. Kunandar. (2009). Guru Profesional: Implementasi Kurikulum Tingkat Satuan Pendidikan (KTSP) dan Sukses dalam Setifikasi guru. Jakarta: Raja wali Pers.

Mulyasa, E. (2013). Manajemen dan Kepemimpinan Kepala Sekolah. Jakarta: PT. Bumi Aksara.

(2013). Implementasi Kurikulum Tingkat Satauan Pendidikan: Kemandirian Guru dan Kepala Sekolah. Jakarta: PT. Bumi Aksara.

-------------. (2013). Menjadi Guru Profesional: Menciptakan Pembelajaran Kreatif dan Menyenangkan. Bandung: Remaja Rosdakarya.

Mukhtar dan Iskandar. (2009). Orientasi Baru Supervisi Pendidikan. Jakarta: Gaung Persada.

Rusman. (2009). Manajemen Kurikulum. Jakarta: Rajawali Pers.

Supardi. (2013). Sekolah Efektif: Konsep Dasar dan Praktiknya. Jakarta: Rajawali Pers. Undang-Undang Nomor 20 Tahun 2003, tentang Sistem Pendidikan Nasional. Gaung Persada 
Undang-Undang Nomor 14 tahun 2005, tentang Guru dan Dosen. Gaung Persada.

Usman, Nasir. (2012). Manajemen Mutu Kinerja Guru: Konsep, Teori dan Model. Bandung: Citapustaka Media Perintis.

Wahjosumidjo. (2011). Kepemimpinan Kepala Sekolah: Tinjauan Teoritik dan Permasalahannya. Jakarta: Rajawali Pers. Wahyudi. (2012). Kepemimpinan Kepala

Sekolah dalam Organisasi Pembelajaran. Bandung: Alfabeta.

Yamin, Martinis. dan Maisah. (2009). Manajemen Pembelajaran Kelas: Strategi Meningkatkan Mutu Pembelajaran. Jakarta: Gaung Persada.

Zainudin dan Sri Langgeng Ratnasari. 2015. Pengaruh Gaya Kepemimpinan, Lingkungan Kerja, Dan Motivasi Terhadap Kinerja Guru Sekolah Dasar Kecamatan Batu Ampar Kota Batam. Jurnal Ekonomi. Zona Manajemen. ISSN 2087-6998. Fakultas Ekonomi Universitas Batam. Volume 7, Nomor 3, Desember 2015. Hal. 14-21 